\title{
A revision of dung flies of the genus Mixocordylura Hendel (Diptera: Scathophagidae), with the description of a new species from Altai
}

\author{
Ревизия скатофагид рода Mixocordylura Hendel (Diptera: \\ Scathophagidae), с описанием нового вида с Алтая
}

\author{
A.L. Ozerov ${ }^{1}$, M.G. Krivosheina ${ }^{2}$ \\ А.А. Озеров ${ }^{1}$, М.Г. Кривошеина ${ }^{2}$
}

\begin{abstract}
${ }^{1}$ Zoological Museum, Moscow Lomonosov State University, Bol'shaya Nikitskaya 6, Moscow 125009, Russia. E-mail: ozerov2455@rambler.ru

1 Зоологический музей, Московский государственный университет им. М.В. Ломоносова, Большая Никитская ул., 6, Москва 125009, Россия

${ }^{2}$ A.N. Severtzov Institute of Ecology and Evolution, Russian Academy of Sciences, 119071 Moscow, Russia. E-mail: dipteramarina@rambler.ru

${ }^{2}$ Институт проблем экологии и эволюции им. А.Н.Северцова РАН, Ленинский проспект, 33, Москва 119071, Россия.
\end{abstract}

KEYWORDS: Diptera, Scathophagidae, Mixocordylura, lectotype, new species.

КЛЮЧЕВЫЕ СЛОВА: Diptera, Scathophagidae, Mixocordylura, лектотип, новый вид.

ABSTRACT. Flies of the genus Mixocordylura Hendel, 1909 including two species, are revised. One of them new to science, Mixocordylura parva Ozerov, is described and Mixocordylura longifacies Hendel, 1909 is redescribed. Lectotype for Mixocordylura longifacies Hendel is designated. Generic diagnosis, keys for determination of both species are given, and data on distribution and biology are summarized.

РЕЗЮМЕ. Ревизованы двукрылые рода Міхоcordylura Hendel, 1909, который включает два вида. Приведено описание Mixocordylura parva Ozerov, нового для науки вида и переописание Mixocordylura longifacies Hendel, 1909. Для последнего вида обозначен лектотип. Даны диагноз рода и ключ для определения обоих видов, а также суммированы данные по их распространению и биологии.

\section{Introduction}

Genus Mixocordylura was described by Hendel and consists of the only species $M$. longifacies Hendel, 1909 , the specimens of which were collected in northen Mongolia by Leder [Hendel, 1909]. Besides detailed description of the genus and species Hendel made figures of head, wing and end of female abdomen of $M$. longifacies.

Grunin [1965] published his work, giving for the first time the figures of male sternite 5 and male genitalia, as well as data on biology of M. longifacies.

Printed in 2012.
Gorodkov [1974] studied stems of Rheum and reared imagoes of $M$. longifacies from them.

While determining materials of Scathophagidae from Altay we discovered one more undescribed species of Mixocordylura. Generic diagnosis, the description of a new species and redescription of $M$. longifacies, keys for determination of both species are given below.

Terminology follows McAlpine [1981] and Cumming et al. [2009]. The following abbreviations are used for depositories of the studied specimens: NMW Naturhistorisches Museum, Wien, Austria; SZMN Siberian Zoological Museum, Institute of Animal Systematics and Ecology, Novosibirsk, Russia; ZMUM Zoological Museum, Moscow State University, Moscow, Russia. Other abbreviations used: $a$ - anterior; $d$ - dorsal; $p$ - posterior; $v$ - ventral; and combinations of these latter four, all used for leg chaetotaxy; LT - lectotype, PLT — paralectotype; ALO Andrey Ozerov.

\section{Taxonomy}

Mixocordylura Hendel

Mixocordylura Hendel, 1909: 778. Gender: feminine. Typespecies: Mixocordylura longifacies Hendel, by original designation.

Proepisternum is covered with setulae at middle or in anterior part. Scutellum with 2 pairs of strong setae. Anepisternum covered with setulae usually along dorsal margin and in posterior part only, without setulae 


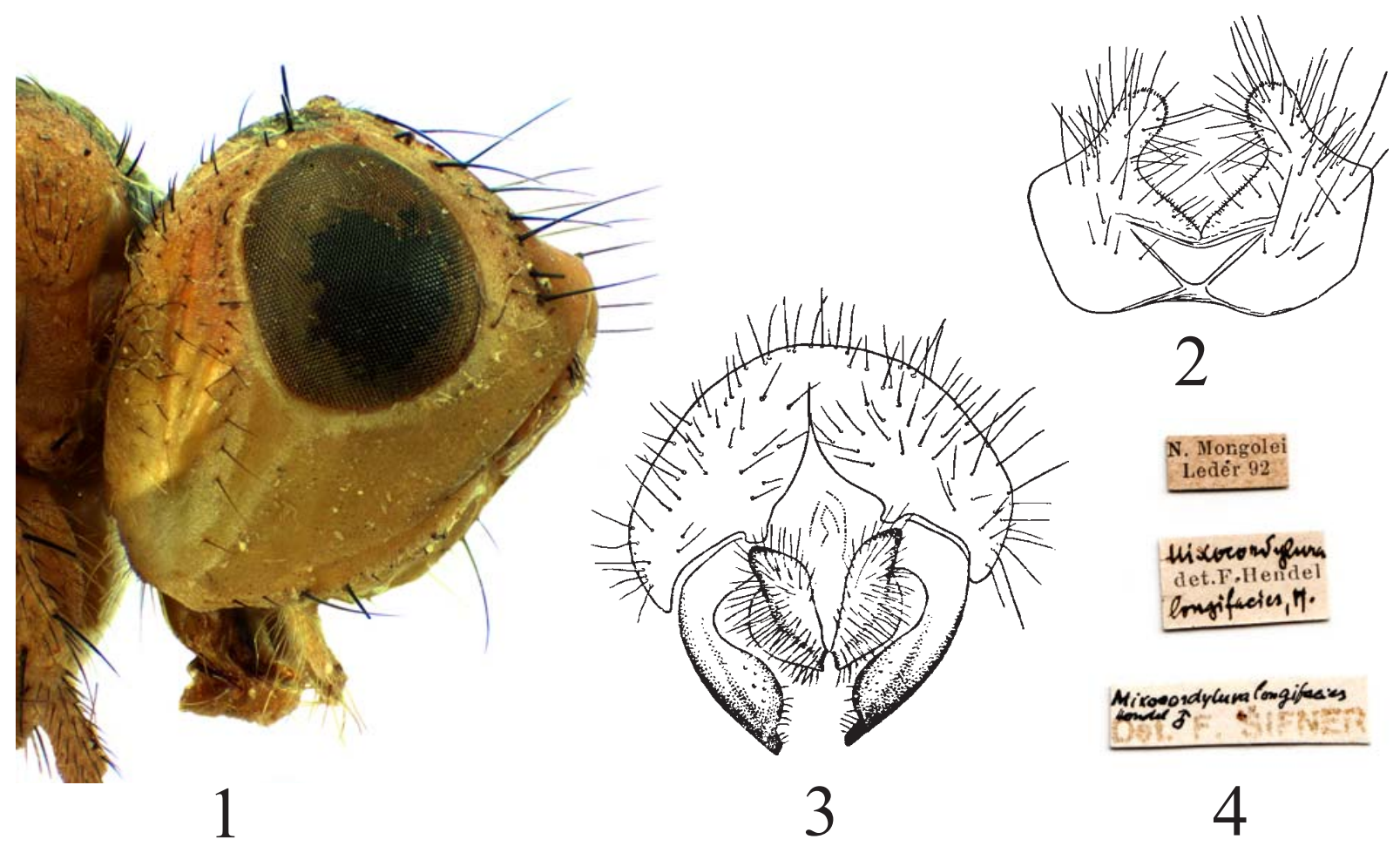

Figs 1-4. Mixocordylura longifacies Hendel: 1 - head, female PLT; 2 - male sternite 5; 3 - epandrium, cerci and surstyli, dorsal view; 4 - labels of LT (2, 3 - after Grunin, 1965).

Pис. 1-4. Mixocordylura longifacies Hendel: 1 - голова, самка PLT; 2 - стернит 5 самца; 3 - эпандрий церки и сурстили, сверху; 4 - этикетки лектотипа (2, 3 - по Grunin, 1965).

posterior to anterior spiracle. Tibia of foreleg of both sexes without anteroventral row of long and strong or spine-like setae. Palpus distinctly spatulate, with setae of approximately equal length, without long apical seta. Vein $\mathrm{R}_{1}$ setulose on apical third of dorsal surface. Katepisternum with a single upper posterior seta. Scutum anteriorly with two erect setae. Postpronotal lobe anteriorly without erect spines. Width of gena equal or about half of vertical diameter of eye. Female abdomen: tergite 7 and sternite 7 divided in two medially and both halves fused laterally, tergite 8 with stout spines, sternite 8 reduced.

\section{Key to species of the genus MixocordyluRa Hendel}

1. Body yellow, only scutum, katepisternum and meron blackish at its central part, and tergites 1-5 blackish basally and centrally. Gena very wide, its width more than vertical diameter of eye (Fig. 1). Width of parafacial more than length of postpedicel. Antennae are hidden inside pit (Fig. 1). Larger - 7-9 mm ..

M. longifacies Hendel

— Thorax and abdomen black, greyish microtrichose. Width of gena about half of vertical diameter of eye (Fig. 10). Width of parafacial less than width of postpedicel. Antennae projecting forward from pit (Fig. 10). Smaller $5-6 \mathrm{~mm}$ M. parva Ozerov, sp.n.

\section{Mixocordylura longifacies Hendel} Figs. 1-4.

longifacies Hendel, 1909: 782 (Mixocordylura). Type-locality: "nördlichen Mongolei" (Mongolia); LT $\sigma^{7}$, by present designation, in NMW.

MATERIAL EXAMINED. Types: see NOTES below.

REDESCRIPTION. MALE, FEMALE. Length of body 7-9 $\mathrm{mm}$. Length of wing 6-8 $\mathrm{mm}$. Body matt, yellow, only vertex blackish around inner vertical setae, scutum, katepisternum and meron blackish at its central part, and tergites $1-5$ blackish basally and centrally. Legs subshining, yellow. Wing yellowish, with yellow veins.

Head (Fig. 1). Parafacial wide, width of parafacial more than length of postpedicel. Gena very wide, its width more than vertical diameter of eye. 2 orbitals, 57 frontals, 1 ocellar, 1 postocellar, 1 inner vertical, 1 outer vertical setae present; 5-6 pairs of not long vibrissae. Postpedicel rounded apically, approximately 2 times as long as wide; arista bare. Palpus distinctly spatulate, without long apical seta.

Thorax. Scutum with 2 postpronotal, 2 notopleural, $1+2$ supra-alar, $1+2$ intra-alar, 2 postalar, and $2+3$ dorsocentral setae; acrostichal hairs in two rows, prescutellar pair well developed and longer than other $a c$ hairs. Proepisternum with setulae and 1 strong seta near ventral margin. Proepimeron bare, but with 1 strong seta near ventral margin. Anepisternum rarely with set- 
ulae in posterior half and 2-3 strong setae near posterodorsal corner. Katepisternum with 1 strong seta in posterodorsal corner. Anepimeron bare. Postmeta-coxal (=postcoxal) bridge absent. Scutellum with 2 pairs of strong setae: basal and apical.

Legs yellow. Forefemur with row of long $p d$ and row of thin $v$ setae; foretibia with $2-3 p, 1$ preapical $d$, $2 p d$, and $2 \mathrm{alad}$ setae. Midfemur with row of $a d$ in basal half and 2-3 preapical $p d$; midtibia with $1 p d$ and 2 ad near middle, and with ring of apical setae. Hindfemur with rows of $a d$ and $v$ setae; hindtibia with $3 p d, 4$ $5 a d$, with 1 preapical $d$, and apical $a v$. face.

Wing. Vein $\mathrm{R}_{1}$ setulose on apical third of dorsal sur-

Abdomen densely microtrichose, in male without striking setae, in female with setae on tergites 3-6 along posterior margin. Female tergite 7 microtrichose. Male sternite 5, epandrium, cerci and surstyli as in Figs 2-3.

NOTES. M. longifacies was described from several specimens of both sexes. ALO has seen male and female syntypes from NMW. The male has labels "N. Mongolei Leder [18]92", "Mixocordylura longifacies, $\mathrm{H}[$ endel] det. F. Hendel", "Mixocordylura longifacies Hendel $\sigma^{7}$ Det. F. Šifner" (Fig. 4). ALO has labelled and designates herewith this $\sigma^{7}$ as lectotype. The lectotype is pinned; right postpedicel, right hind leg and right wing are lost; abdomen cut and its parts are glued on carton card on the same pin as the specimen. The female with the same labels as lectotype ALO labelled as paralectotype. There are two more females in NMW, also labelled by ALO as paralectotypes. Figures given by Grunin [1965] of male sternite 5 and genitalia concide with lectotype.

\section{Mixocordylura parva Ozerov, sp.n.} Figs. 5-10.

MATERIAL. Holotype $\sigma^{7}$, RUSSIA: Altay, Kuraysky range, 2500-2700 $\mathrm{m}\left(50.33^{\circ} \mathrm{N}, 87.75^{\circ} \mathrm{E}\right)$, montain tundra, 3.VII.2008, $\grave{A}$ Barkalov (SZMN). The holotype is pinned; in very good condition, with abdomen cut and mounted in tube with glycerol on the same pin with the specimen.

Paratypes: 1 , RUSSIA: Altay, Ukok plateau, $6 \mathrm{~km}$ NE of Maytobe, $2600-2800 \mathrm{~m},\left(49.34^{\circ} \mathrm{N}, 87.43^{\circ} \mathrm{E}\right)$, 8.VII.2006, V. Sorokina $(\mathrm{SZMN}) ; 1$ \%, RUSSIA: Altay, Shebalinsky Distr., Seminsky pass, $1748 \mathrm{~m},\left(51.05^{\circ} \mathrm{N}, 85.02^{\circ} \mathrm{E}\right), 20 . \mathrm{VI} .2009$, V. Sorokina (SZMN); 2 우, RUSSIA: Altay, Ust'-Koksa [District], Katunsky range, Kamdyt, 2150-2514 (4958.7-59.14'N, 86 $\left.33-34.9^{\circ} \mathrm{E}\right)$, 28.VI.-4.VII.2007, subalpine and alpine meadows, birch tundras, stone screes, leg. O. Kosterin (ZMUM).

DESCRIPTION. MALE, FEMALE. Length of body 5-6 mm. Length of wing 4.8-5.5 $\mathrm{mm}$.

Head (Fig. 10). Frons matt, yellow. Eye orbit blackish in upper half and yellow in lower half, whitish microtrichose. Ocellar triangle and postcranium black with whitish microtrichia. Face yellow, gena dark yellow, both whitish microtrichose. Width of parafacial approximately equal to width of postpedicel. Width of gena less than vertical diameter of eye (Fig. 10). 2-3 orbitals, 5-6 frontals, 1 ocellar, 1 postocellar, 1 inner vertical, 1 outer vertical setae present; 2 pairs more or less equal vibrissae and 4-5 pairs of small subvibrissae. Antennae yellow. Postpedicel rounded apically, approximately 2 times as long as wide; arista very short pubescent. Palpus distinctly spatulate, without long apical seta.

Thorax black, greyish microtrichose. Scutum with 2 postpronotal, 2 notopleural, $1+2$ supra-alar, $1+2$ intra-alar, 2 postalar, and $2+3$ dorsocentral setae; acrostichal hairs in two rows, prescutellar pair not differentiated or only slightly longer than the other $a c$ hairs. Proepister-num with setulae and 1 strong seta near ventral margin. Proepimeron with 2-3 hairs and 1 strong seta near ventral margin. Anepisternum rarely with setulae in posterior half and 2-3 strong setae near posterodorsal corner. Katepisternum with 1 strong seta in posterodorsal corner. Anepimeron bare. Postmetacoxal (=postcoxal) bridge absent. Scutellum with 2 pairs of strong setae: basal and apical.

Legs. Coxae black, only forecoxa sometimes yellowish in lower half; trochanters yellow; femora black, but yellow basally and at apical quarter; tibiae and tarsi yellow. Forefemur with row of long $p d$ setae and row of long $v$ setulae; foretibia with $2 p, 1$ preapical $d$, $1 \mathrm{~d} / \mathrm{ad}$, and $1 \mathrm{pd}$ setae. Midfemur with row of $\mathrm{ad}$ and 2-3 preapical $p d$; midtibia with $1 p, 1-2 p d$ and 1-2 ad near middle, $1 a v$, and with ring of apical setae. Hindfemur with rows of $a d$ and $a v$ setae; hindtibia with 2-3 $p d, 2-3 a d, 0-2 a v, 1$ preapical $d$, and several apical setae.

Wing with yellow tinge, veins brown. Vein $\mathrm{R}_{1}$ setulose on apical third of dorsal surface.

Abdomen black, densely microtrichose; female segment 8 reddish; in male without striking setae, in female with setae on tergites 4-6 along posterior margin. Female tergite 7 microtrichose. Male sternites 4 and 5, epandrium, cerci and surstyli as in Figs 5-8. Female ovipositor as in Fig. 9: both tergite 7 and sternite 7 divided in two medially and both halves fused laterally, tergite 8 with stout spines, sternite 8 reduced.

COMPARISON. The new species differs distinctly from $M$. longifacies in body coloration, size of eye, gena and parafacial (see key above), but close in the structure of male sternite 5 (Fig. 6 and Fig. 2), male genitalia (Fig. 8 and Fig. 3) and female ovipositor.

\section{Distribution and biology}

The data on distribution and biology of Mixocordylura are very scanty. Leder collected M. longifacies in June in northern Mongolia [Hendel, 1909]. Basing on the structure of ovipositor Hendel [1909] supposed this species to develop in plant tissue.

Grunin [1965] collected the flies of M. longifacies in June on stems of flowering Rheum sp. in steppy zone of Transbaikal $(700 \mathrm{~m})$ and in south-east Altay (2300$3500 \mathrm{~m}$ ). However he did not observe females laying eggs on this plant.

Gorodkov [1974] collected the adult of $M$. longifacies in June on arround Ulan-Bator (Mongolia). He 


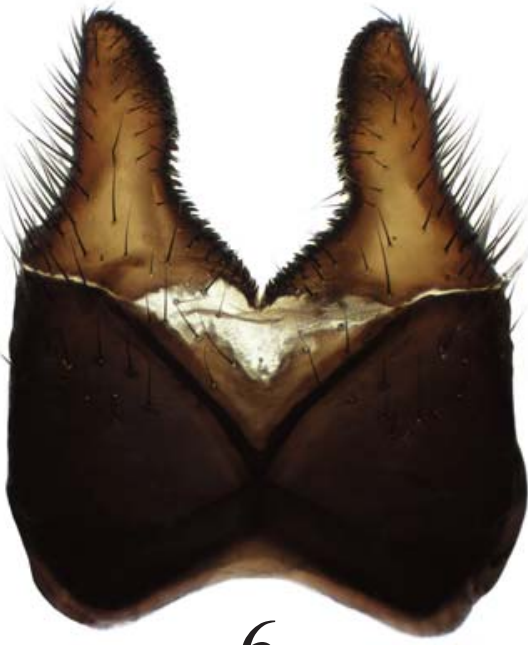

6

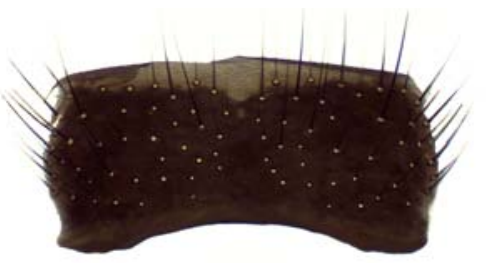

5

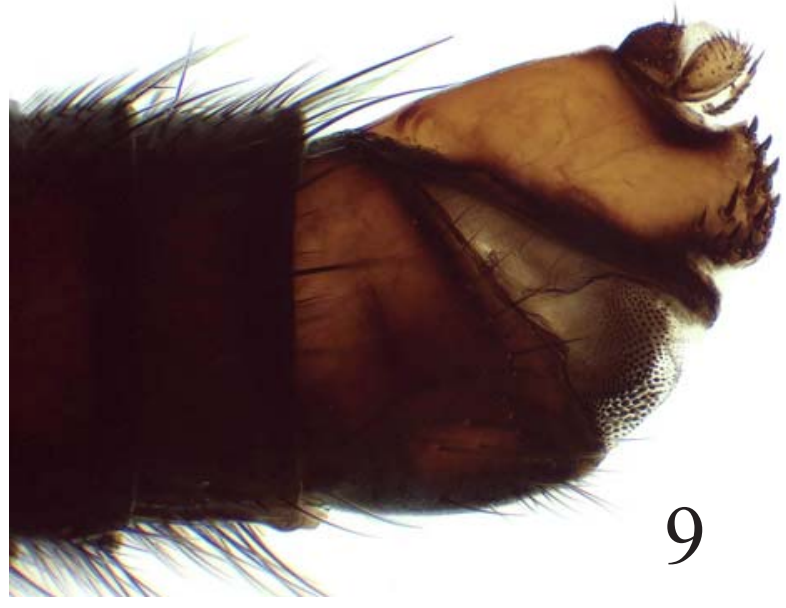

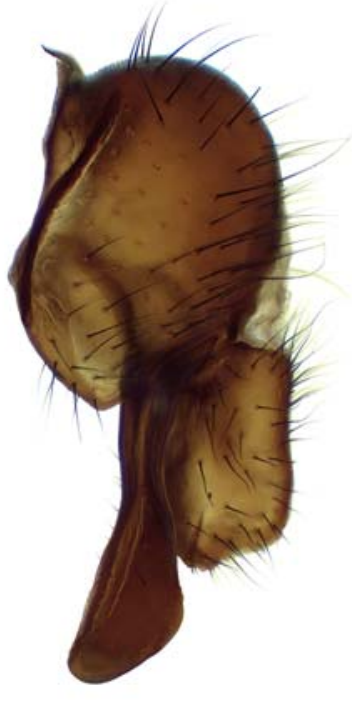

7

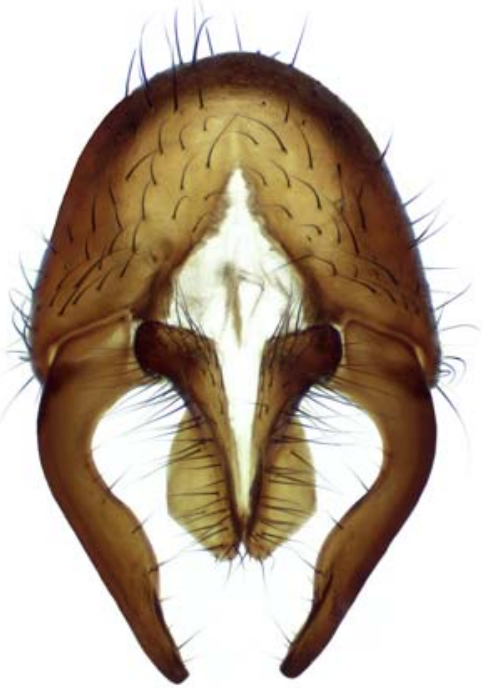

8

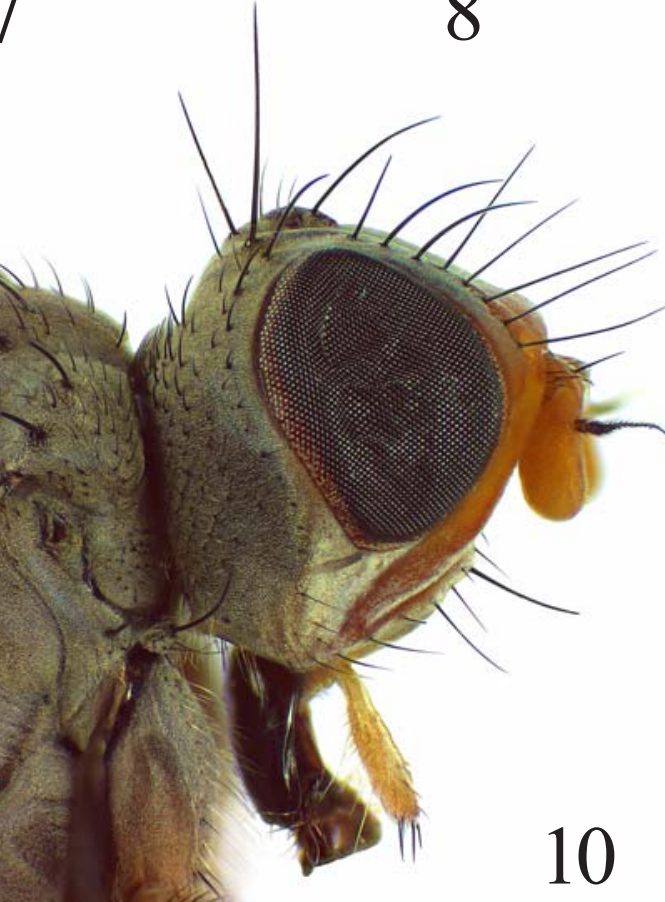

Figs 5-10. Mixocordylura parva Ozerov, sp.n.,: 5 - male sternite 4; 6 - male sternite 5; 7 - epandrium, cercus and surstylus, lateral view; 8 - epandrium, cerci and surstyli, dorsal view; 9 - female abdominal end, lateral view; 10 - head of male.

Рис. 5-10. Mixocordylura parva Ozerov, sp.n.: 5 - стернит 4 самца; 6 - стернит 5 самца; 7 - эпандрий, церк и сурстиль, сбоку; 8 - эпандрий церки и сурстили, сверху; 9 - кончик брюшка самки, сбоку; 10 - голова, самец.

studied stems of Rheum taken from Buryatia and reared imagoes of M. longifacies [Gorodkov, 1974].

There are two well distinguished species of Rheum in Siberia and to east of Baikal: Rheum rhabarbarum Linnaeus and $R h$. compactum Linnaeus ( $=R h$. altaicum Losinsk.). Wild Rh. rhabarbarum is distributed in Altay (south-east), in Transbaikal and in Mongolia, and is planted in gardens in West Siberia. Rh. compactum is known from montain areas of West Altay. So, most likely larvae of M. longifacies developed in Rheum rhabarbarum.

Biology of $M$. parva is unknown. All the three sites of collecting of $M$. parva were situated at high mountains and above or near the upper border of forest belt, though, as the collector of the species, O. Kosterin, informed us, Rheum is known from lower level too. Kosterin collected imago of $M$. parva on stone screes (see labels above). 
ACKNOWLEDGEMENTS. We wish to thank Dr. Peter Sehnal (NMW) for the loan of Mixocordylura longifacies types, Dr. Anatoly Barkalov (Novosibirsk) and Dr. Oleg Kosterin (Omsk) for the loan of Mixocordylura material from Altay.

\section{References}

Cumming J.M., Wood D.M. 2009. Adult morphology and terminology. Pp. 9-50. In Brown B.V., Borkent A., Cumming J.M., Wood D.M., Woodley N.E., Zumbado M. (eds.). Manual of Central American Diptera. Vol. 1. National Research Council Press, Ottawa.
Gorodkov K.B. 1974. Scatophagidae (Diptera) of Mongolian People's Republic. Nasekomye Mongolii. T.2. P.380-395 [in Russian].

Grunin K. J. 1965. [On the biology of the genus Mixocordylura Hendel (Diptera, Cordyluridae), new to the fauna of the USSR]. Entomologicheskoe Obozrenie. Vol.44. No.3. P.584-585 [in Russian].

Hendel F. 1909. Über eine neue paläarktische Cordylurinen-Gattung. (Dipt.) // Deutsche Entomologische Zeitschrift. Heft 6. S.777-782.

McAlpine, J. F. 1981. Morphology and terminology-adults. Pp. 963. In: McAlpine J.F., Peterson B.V., Shewell G.E, Teskey H.J., Vokeroth J.R., Wood D.M., Coordinators. Manual of Nearctic Diptera. Volume 2. Research Branch. Agriculture Canada. Monograph 27, Ottawa. Vi+674 pp. 